\title{
Assessing Behaviour and Attitude of School Students towards Environmental Issues - A Case Study from Delhi, India
}

\author{
Kanchan Puri ${ }^{1}$, A. Senthil Vel ${ }^{1}$, N. Manoharan ${ }^{2}$, R. Arthur James ${ }^{2}$ and Ritesh Joshi ${ }^{1}$ \\ ${ }^{1}$ Ministry of Environment, Forest and Climate Change, Government of India, New Delhi, India \\ ${ }^{2}$ Department of Marine Science, Bharathidasan University, Tiruchirappalli, India \\ *Corresponding author: genetics_1407@yahoo.co.in
}

Received: 20-11-2019 Revised: 27-02-2020 Accepted: 24-03-2020

\begin{abstract}
Environmental education has been introduced as a regular course in formal school education system following the directive of the Honourable Supreme Court of India. The research work aimed to assess the level of environmental awareness and the existing environmental friendly activities among the students of High Schools. The population for the study was the students of schools in Delhi covering IX and X class. This study is primarily based on field survey, wherein students responded to predefined questionnaire covering environment aspects. The survey was conducted during May 2019. A total of 160 students were randomly selected and students responded voluntarily. Questionnaire was compiled to assess student's environmental behaviour, attitude, information sources and demographic information. It has been observed that students highly support the environmental attitude and have sound behaviours towards their actions effecting the environment. The study highlighted that many young minds adapted an environmentally friendly attitude and the green attitude is clearly visible in their actions.
\end{abstract}

Keywords: Environment education, students, attitude, behaviour, Delhi

The basic support to the life on this planet is through Environment. The deterioration of environment has been a cause of concern and therefore Environmental awareness is essential to harmonize patterns of individual behaviour for its conservation. Environmental awareness implies knowledge about environment and inculcates values and skills to solve environmental issues and it is a initial step leading to carry responsible citizenship behaviour (Sengupta, Das and Maji, 2010). Awareness involves not only internalization of environmentally responsible behaviour, but also enhanced understanding of the impacts of irresponsible actions. Environment education (EE) is the principle means of enhancing such environment awareness, both among the public at large, and among focused groups. Such education may be formal, or informal, or a combination of both. EE is recognized as the process that would help individuals to acquire essential knowledge and skills to take positive actions towards a better environment. It has become imperative to make $\mathrm{EE}$ as a tool for life-long learning right from one's childhood. EE can be defined as a process of developing a community that is aware of, concerned about, the total environment and its associated paradigms and which has the knowledge, attitudes, commitments and skills to work individually and collectively towards the situation of current problems and prevention of new ones (Sonowal, 2009). Hence EE possesses the capabilities to change the attitude of people, generating critical thinking and actions.

After the first United Nations Conference on Human Environment held in Stockholm in 1972, EE started gaining momentum globally. It became a focal point of the world community, when first Inter-Governmental Conference on Environmental 
Education was held in Tbilsi in 1977. The conference recommended that EE should be able to create awareness, give knowledge, develop skills and attitude, and larger participation of people towards the burning global issues of environment. Another report of Independent Commission on International Development Issues (Brundtl 1987) also incorporated $\mathrm{EE}$ as a challenge for the global community. The United Nations Conference held in Rio-de-Janerio, Brazil (1992) stressed upon the public awareness through intensification of education and training related to environment and development. The United Nations General Assembly in December 2002, dedicated a UN Decade to Education for Sustainable Development, 2005- 2014, to focus attention on the key role education play in fostering sustainable development. One of the key thrusts of the decade was to integrate understanding of sustainable development into education systems - at all levels and to reorient educational programmes, policies and practices so that education plays its part in building the capacities of all members of society to work together for a sustainable future.

In India, the universalization of EE was mandated by Supreme Court Order on 22nd November 1991. Hon'ble Supreme Court in its judgment of 18th December 2003 directed that the NCERT shall prepare a model syllabus. In the year 2004, Hon'ble Supreme Court issued further directions, that "the syllabus prepared by the NCERT for class $1^{\text {st }}$ to $12^{\text {th }}$ shall be adopted by every state in their schools". The National Curricular Framework 2005 was another landmark initiative in which infused and integrated approach to Environment Education was laid and habitat of students and its relation with learning was emphasized. India is one of the few countries in the world, where EE is compulsory at all levels of formal education (Sharma and Menon, https:// thegeep.org/index.php/learn/case-studies).

The present study aims to give insight on the understanding of students towards environmental issues in Delhi, which is a metropolitan city currently suffering from the severe air pollution problem. The study explored the participant's environmental attitude and behavior considering the fact that EE has become part of school curricula.

\section{MATERIALS AND METHODS}

Environmental attitude is directly linked with the level of knowledge regarding environmental issues possessed by an individual, and behaviour is if he/ she modify his/ her daily life activities in view of the knowledge attained. The research work aimed to assess the level of environmental awareness and the existing environmental friendly activities among the students of High Schools. The population for the study was the students of schools in Delhi covering IX and $X$ class. Literature reveals that most of the researchers have used questionnaires as a tool to collect data on assessing environment education levels. This study is primarily based on field survey, wherein students responded to predefined questionnaire covering environment aspects. The survey was conducted during May 2019. A total of 160 students were randomly selected and students responded voluntarily (Fig 1). Questionnaire was compiled to assess student's environmental behaviour, attitude, information sources and demographic information. To assess the environment attitude the questionnaire was made on 5 point likert scale which ranged from 1 (strongly agree) to 5 (strongly disagree). Remaining questions were given the option of yes or no. The responses were then computed in excel format. Further since environmental information is very crucial in helping young people acquire knowledge about their environment, students were also asked about the main source of information about environmental issues and given options: Television/ School/Newspaper/Magazines/Radio/Family and Others. Information acquired through the different or various sources will go a long way in raising their awareness and helping them change their negative attitude or behaviour to be positive.

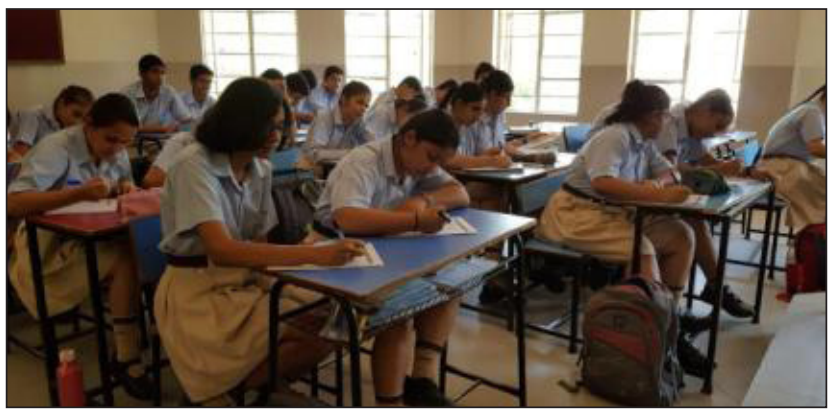

Fig. 1: Students filing the questionnaire in the school

\section{RESULTS AND DISCUSSION}

Of the total 160 students, $54 \%$ were female students and $46 \%$ male (Table 1). Average age of the 
respondents was 16 years and they belonged from the urban areas of Delhi. It was found that $45 \%$ of the students strongly agreed that EE be taught as a separate subject whereas $17 \%$ were neutral. The same set believed that environment education should be a mandatory subject, however they also strongly agreed that studying EE will bring additional load to the curricula. But they were ready to learn about the environment, through the environment and for the environment. Further $60 \%$ of them indicated that Government of India should impose high penalty fine that disobey environment rules. Data has been tabulated in Table 2. During the survey, it was also noticed that the students were more sensitive to environmental problems in their own living areas that those in other areas.

Table 1: Percentage of total population of the study

\begin{tabular}{ccc}
\hline Particular & Number & \% \\
\hline Male & 74 & 46.25 \\
Female & 86 & 53.75 \\
\hline Total & $\mathbf{1 6 0}$ & $\mathbf{1 0 0}$ \\
\hline
\end{tabular}

Change in behaviour for positive environmental actions can't be achieved overnight nor it can be a onetime exercise, it is a constant process. To assess the behaviour of the students the descriptive questions were asked: (1) If you see someone throwing/burning garbage on road, open areas etc. will you dare to stop that man, (2) If you see garbage on road, open areas etc. will you pick up the garbage and throw it in dustbin, (3) Will you pay/donate to clean up the environment, (4) Will you participate in awareness programme for environment conservation, (5) When you go to a national park, zoo, tiger reserves, do you carry waste bag, (6) Will you promote carpooling, (7) Will you opt for public transport, (8) Do you use CNG cars and (9) Do you carry jute/cloth bags while shopping. 98\% replied with YES option for the questions. They were aware of ill health effects of plastics, air pollution, water pollution and public sanitation. It is also inferred from the table 3 that $66.8 \%$ highlighted that the effective method to create environment awareness is through social media whereas the main source of environment information was received through school (60.6\%) table 4 .

Time has come where the phrase 'Only the rich people can afford the luxury of clean environment' is changing. The rich and developed countries too are facing environment problem. For example in

Table 2: Part of the questionnaire to assess the attitude towards environment education

\begin{tabular}{|c|c|c|c|c|c|c|c|c|}
\hline Scale & $\begin{array}{c}\text { Should } \\
\text { Environment } \\
\text { education (EE) } \\
\text { be a separate } \\
\text { subject? }\end{array}$ & $\%$ & $\begin{array}{l}\text { Should } \\
\text { environment } \\
\text { education be } \\
\text { mandatory }\end{array}$ & $\%$ & $\begin{array}{l}\text { Does studying } \\
\text { EE will bring } \\
\text { additional load to } \\
\text { your curricula }\end{array}$ & $\%$ & $\begin{array}{c}\text { Do you think } \\
\text { Government should } \\
\text { impose high penalty } \\
\text { fine who disobey } \\
\text { environment rules? }\end{array}$ & $\%$ \\
\hline Strongly Disagree & 0 & 0 & 0 & 0 & 0 & 0 & 0 & 0 \\
\hline Disagree & 0 & 0 & 4 & 2.5 & 19 & 11.87 & 5 & 3.12 \\
\hline Strongly agree & 72 & 45 & 74 & 46.25 & 69 & 43.12 & 96 & 60 \\
\hline Total & 160 & 100 & 160 & 100 & 160 & 100 & 160 & 100 \\
\hline
\end{tabular}

Table 3: Effective method to create environment awareness

\begin{tabular}{ccc}
\hline & $\begin{array}{c}\text { Which is the most effective method to create } \\
\text { environment awareness }\end{array}$ & $\%$ \\
\hline Social media & 107 & 66.87 \\
Seminar & 33 & 20.62 \\
Film shows & 4 & 2.5 \\
Debates & 3 & 1.87 \\
Paintings & 0 & 0 \\
Awareness campaigns (mass rally) & 6 & 3.75 \\
Nukad nataks & 7 & 4.37 \\
\hline Total & $\mathbf{1 6 0}$ & $\mathbf{1 0 0}$ \\
\hline
\end{tabular}


Delhi, the rich section is also trapped in the same gas chamber which is filled with air pollution. It all depends on the coming generation how they build their environmental consciousness. It is very important that environment education is given utmost priority and importance as only educated people educate others.

Table 4: Main source of environment information

\begin{tabular}{ccc}
\hline & $\begin{array}{c}\text { Main source of } \\
\text { environment } \\
\text { information }\end{array}$ & $\mathbf{\%}$ \\
\hline Television & 14 & 8.75 \\
School & 97 & 60.63 \\
Newspaper / Magazines & 42 & 26.25 \\
Radio & 0 & 0.00 \\
Family & 5 & 3.125 \\
Others & 2 & 1.25 \\
\hline Total & $\mathbf{1 6 0}$ & $\mathbf{1 0 0 . 0 0}$ \\
\hline
\end{tabular}

But it is also a fact that only once people have reasonable standard of living they can afford to think about the environment. It was interesting to note that despite these students were having high environmental attitude as well as behaviour but only $42.5 \%$ wanted to pursue their career in the Environment field, table 5. The reason may be attributed to the fact that there is lack of awareness on the environment jobs, however this aspect needs to be studied in detail.

Table 5: Student's response towards environment as career option

\begin{tabular}{ccc}
\hline & $\begin{array}{c}\text { Pursue Career in } \\
\text { Environment }\end{array}$ & \% \\
\hline Yes & 68 & 42.5 \\
No & 92 & 57.5 \\
\hline Total & $\mathbf{1 6 0}$ & $\mathbf{1 0 0}$ \\
\hline
\end{tabular}

\section{CONCLUSION}

Students have always played an active role in the activities leading to the development of environmental awareness. It is very important and essential that these children of today who will hold the baton of tomorrow should be environmentally conscious. In this study, it has been observed that students highly support the environmental attitude and it was also found that the students equally showed environmental responsible behaviour like carpooling, using cloth bags while shopping, segregating waste etc. Most importantly they are willing to learn more about environment, nature ecology subjects by attending conferences, seminars, workshops about environmental education.

The students have a fair knowledge on environmental issues which can be attributed to the various ongoing programmes like Ecoclub programme of Ministry of Environment, Forest and Climate Change which is an annual programme under which students take part in various environment related activities. Various important environment days like World Environment Day, Earth Day, Wetland day, Forest day etc are celebrated in school wherein students take part in debates, essays, poster / drawing competitions which enable them to think/discuss these days and related themes. Thinking process on the emerging environmental problems is developed in these students, although the knowledge needs to be build upon further. Educational value of sources like TV, newspapers, radio needs to be maximised so that it could be used as powerful tool to change behaviour.

The study highlighted that many young minds adapted an environmentally friendly attitude and the green attitude is clearly visible in their actions. Further there is a need to incentivise and bring motivation to these students who wants to pursue career in environment conservation field just like NCC/NSS cadets gets reservation quota in jobs, similarly some weightage should be given to those who adopt environmental courses. These children have developed responsible thinking that we have to live in harmony with nature and don't want to become tomorrow's polluters.

\section{ACKNOWLEDGEMENTS}

Sincere thanks to the school students and teachers who participated in the survey and showed their interest to respond voluntarily. Special thanks to Ms Renuka Sahu, Teacher for her efforts and school management for allowing authors to conduct the survey.

\section{REFERENCES}

DESD (Decade of Education for Sustainable Development) http://www.desd.org/.

Sengupta, M., Das, J. and Maji, R.K. 2010. Environmental Awareness and Environmental Related Behaviour of Twelfth Grade Students in Kolkata: Effects of Stream and Gender, Anwesa, 5: 1 - 8 . 
Sharma, P.K. and Menon S. GEEP Case Study: Compulsory Environmental Education in India. Available at https:// thegeep.org/sites/default/files/2019-04/case_study_ complusory_ee_-_india_final.pdf.

Sonowal, C.J. 2009. Environmental Education in Schools: The Indian Scenario, Journal of Human Ecology, 28(1): 15-36.
The UN Decade of Education for Sustainable Development (DESD 2005-2014) http://unesdoc.unesco.org/ images/0015/001540/154093e.pdf .

UNESCO (1978): Tbilisi Declaration (Final report of the International conference of EE: Tbilisi (USSR), 11-26 October 1977). Paris: UNESCO. 
